\title{
Salmonella Serotype Newport
}

National Cancer Institute

\section{Source}

National Cancer Institute. Salmonella Serotype Newport. NCI Thesaurus. Code C86921.

Any bacterial organism that can be assigned to the genus Salmonella with serotype Newport. 